\title{
Discovery of complex metal oxide materials by rapid phase identification and structure determination
}

DOI:

$10.1021 /$ jacs.9b00093

\section{Document Version}

Accepted author manuscript

Link to publication record in Manchester Research Explorer

\section{Citation for published version (APA):}

Li, J., Lin, C., Min, Y., Yuan, Y., Li, G., Yang, S., Manuel, P., Lin, J., \& Sun, J. (2019). Discovery of complex metal oxide materials by rapid phase identification and structure determination. Journal of the American Chemical Society. https://doi.org/10.1021/jacs.9b00093

\section{Published in:}

Journal of the American Chemical Society

\section{Citing this paper}

Please note that where the full-text provided on Manchester Research Explorer is the Author Accepted Manuscript or Proof version this may differ from the final Published version. If citing, it is advised that you check and use the publisher's definitive version.

\section{General rights}

Copyright and moral rights for the publications made accessible in the Research Explorer are retained by the authors and/or other copyright owners and it is a condition of accessing publications that users recognise and abide by the legal requirements associated with these rights.

\section{Takedown policy}

If you believe that this document breaches copyright please refer to the University of Manchester's Takedown Procedures [http://man.ac.uk/04Y6Bo] or contact uml.scholarlycommunications@manchester.ac.uk providing relevant details, so we can investigate your claim.

\section{OPEN ACCESS}


This document is confidential and is proprietary to the American Chemical Society and its authors. Do not copy or disclose without written permission. If you have received this item in error, notify the sender and delete all copies.

\section{Discovery of complex metal oxide materials by rapid phase identification and structure determination}

\begin{tabular}{|r|l|}
\hline Journal: & Journal of the American Chemical Society \\
\hline Manuscript ID & ja-2019-00093s.R2 \\
\hline Manuscript Type: & Article \\
\hline Date Submitted by the & 05-Mar-2019 \\
\hline Complete List of Authors: & $\begin{array}{l}\text { Li, Jian; Peking University, College of Chemistry and Molecular } \\
\text { Engineering } \\
\text { Lin, Cong; Peking University Shenzhen Graduate School, School of } \\
\text { Advanced Materials } \\
\text { Min, Yuxin; Peking University Shenzhen Graduate School } \\
\text { Yuan, Youyou; Peking University } \\
\text { Li, Guobao; Peking University, Chemistry } \\
\text { Yang, Sihai; University of Manchester, School of Chemistry } \\
\text { Manuel, Pascal; Diamond Light Source Ltd, } \\
\text { Lin, Jianhua; Peking University, College of Chemistry and Molecular } \\
\text { Engineering } \\
\text { Sun, Junliang; Peking University, College of Chemistry and Molecular } \\
\text { Engineering }\end{array}$ \\
\hline
\end{tabular}

\section{SCHOLARONE Manuscripts}




\section{INTRODUCTION}

Metal oxides constituted an enormous group of solids exhibiting a wide variety of atom structures and electronic structures, which make them process abundant properties and variety of applications. For example, many fluoritestructured oxides (doped $\mathrm{ZrO}_{2}$, doped $\mathrm{CeO}_{2}$ ), pervoskitestructured oxides $\left((\mathrm{Sr}, \mathrm{Mg})\right.$-doped $\left.\mathrm{LaGaO}_{3}\right)$ are used as oxide electrolyte materials ${ }^{[1-2]}$. A number of layeredstructured ternary oxides, $\mathrm{Li}_{\mathrm{x}} \mathrm{M}_{\mathrm{y}} \mathrm{M}_{1-\mathrm{y}}^{\prime} \mathrm{O}_{2}\left(\mathrm{M}, \mathrm{M}^{\prime}=\mathrm{V}, \mathrm{Cr}, \mathrm{Mn}\right.$, $\mathrm{Co}$ and $\mathrm{Ni}, 0<\mathrm{y}<1)$ are used as cathode material for lithiumion batteries (LIB) ${ }^{[3-4]}$. Many copper based oxides have been discovered to be high-temperature oxide superconductor, such as $\mathrm{La}_{2-\mathrm{x}} \mathrm{A}_{\mathrm{x}} \mathrm{CuO}_{4}$ (A=alkaline earth) with $\mathrm{K}_{2} \mathrm{NiF}_{4}$ structure ${ }^{[5]}, \mathrm{LnBa}_{2} \mathrm{Cu}_{3} \mathrm{O}_{7-\mathrm{x}}(\mathrm{Ln}=\mathrm{Y}$ or rare earth other than $\mathrm{Ce}$, $\operatorname{Pr}$ and $\mathrm{Tb}$ ) with 123 type ${ }^{[6]}$. Metal oxides can be semiconducting, which leads to applications in sensors, electronics, and solar cells. Therefore, searching new metal oxide materials with new structure types and useful functionalities are the intriguing fields for chemists or materials scientists.

However, many factors, such as raw materials, chemical component ratio, reaction temperature, reaction time, must be carefully selected and optimized during the practice of new materials synthesis. The conventional one-by-one method for new metal oxide materials synthesis takes a lot of time and energy. To compete successfully and claim priority with new metal oxides materials, one must be able to accelerate the pace of the optimization process. One of the breakthroughs in new materials synthesis is extending the techniques of combinatorial chemistry and high-throughput screening to the field of materials science ${ }^{[7-9]}$. In the combinational approach, a large number of compounds with different compositions are synthesized and characterized together in parallel. With such effectiveness of approach, many new compounds in the key technological areas including optical, dielectric and magnetic materials have been successfully discovered [10-12]. But the phase identification and structure determination are still the 
challenges as it is not easy to obtain a pure phase or single crystal when discovering new materials ${ }^{[13]}$. Fortunately, the new developed three-dimensional electron diffraction (3D ED) method is a preferring option to accelerate the discovery of new materials when only polycrystalline impure samples are available. Firstly, the crystal structure was solved by 3D ED methods (automated diffraction tomography, ADT [14], and rotation electron diffraction, RED ${ }^{[15]}$ ) roughly, the synthesis conditions were then modified and pure samples were finally obtained. In the following, the fine structure was determined by combining Rietveld refinements upon powder $\mathrm{X}$-ray diffraction (XRD) data and other techniques (powder neutron diffractions (PND), IR and solid-state NMR spectroscopy) ${ }^{[16]}$.

In this study, the 3D ED technique, rotation electron diffraction (RED), was employed to explore new complex metal oxide materials in the $\mathrm{Bi}_{2} \mathrm{O}_{3}-\mathrm{Fe}_{2} \mathrm{O}_{3}-\mathrm{TiO}_{2}$ system and rapidly accomplish phase identification and structural determination. The oxidation states, ionic radius and electron configuration of $\mathrm{Bi}^{3+}, \mathrm{Fe}^{3+}$ and $\mathrm{Ti}^{4+}$ were different, which opened up great opportunities to discover new metal oxide materials with hitherto unknown structure types and useful functionalities when combining them into one structure. So far, only two layered perovskite-based structure $\left(\mathrm{Bi}_{3 \mathrm{n}+1} \mathrm{Ti}_{7} \mathrm{Fe}_{3 \mathrm{n}-3} \mathrm{O}_{9 \mathrm{n}+11}, \mathrm{n}=3-6\right.$ and $\mathrm{Bi}_{\mathrm{m}+1} \mathrm{Fe}_{\mathrm{m}-3} \mathrm{Ti}_{3} \mathrm{O}_{3 \mathrm{~m}+3}, \mathrm{~m}=3,4$, $4.5,5,5.5,6,6.5,7,7.5,8,8.5,9)$ were reported in the $\mathrm{Bi}_{2} \mathrm{O}_{3}-\mathrm{Fe}_{2} \mathrm{O}_{3}-\mathrm{TiO}_{2}$ ternary system ${ }^{[17-18]}$. Herein, three new complex metal oxide materials $\left(\mathrm{BiTi}_{0.855} \mathrm{Fe}_{1.145} \mathrm{O}_{4.93}\right.$ 、 $\mathrm{BiTi}_{4} \mathrm{FeO}_{11} 、 \mathrm{BiTi}_{2} \mathrm{FeO}_{7}$ ) with new structure types were discovered by 3D ED techniques. Although all of them were originally a minor phase in a multiphase powder sample, the structures were rapidly solved by the RED technique. After modifying the synthesis condition under the guidance of structure model, the pure samples of all three new metal oxide materials were obtained. Finally, the fine structures were obtained by Rietveld refinements of combination PXRD with PND. The most striking feature of the $\mathrm{BiTi}_{0.855} \mathrm{Fe}_{1.145} \mathrm{O}_{4.93}$ is the presence of five-coordinated iron/titanium. Another new phase $\mathrm{BiTi}_{4} \mathrm{GaO}_{11}$, which is isostructural with $\mathrm{BiTi}_{4} \mathrm{FeO}_{11}$, can be obtained when replacing $\mathrm{Fe}$ in $\mathrm{BiTi}_{4} \mathrm{FeO}_{11}$ with $\mathrm{Ga}$. Our achievement in the case of $\mathrm{Bi}_{2} \mathrm{O}_{3}-\mathrm{Fe}_{2} \mathrm{O}_{3}-\mathrm{TiO}_{2}$ system represents a successful strategy of developing new materials.

\section{EXPERIMENTAL SECTION}

Synthesis. The samples were synthesized using citrate gel methods. Due to the existence of two known layered perovskite-based materials in the $\mathrm{Bi}$ rich area, seven compositions in $\mathrm{Bi}$ poor region of $\mathrm{Bi}_{2} \mathrm{O}_{3}-\mathrm{Fe}_{2} \mathrm{O}_{3}-\mathrm{TiO}_{2}$ system were selected (Figure $\mathrm{S} 1$ ), using $\mathrm{Bi}_{2} \mathrm{O}_{3}$, iron powder and tetrabutyl titanate as the starting materials. First, $\mathrm{Bi}_{2} \mathrm{O}_{3}$ and iron powder were dissolved in $20 \mathrm{~mL}$ diluted $\mathrm{HNO}_{3}(5 \mathrm{M})$ to form aqueous solutions. Citric acid was then added into the $\mathrm{Bi}-\mathrm{Fe}$ solution to form complexing solution, and the molar ratio of metal ions to citric acid was 1:3. Finally, the tetrabutyl titanate was dropped into the Bi-Fe solution with stirring at a temperature of $80{ }^{\circ} \mathrm{C}$. With the evaporation of superfluous water under continuous heating and constant stirring, Bi-Fe-Ti complexing solution became a sol-gel. The resulting gel was dried at $200{ }^{\circ} \mathrm{C}$ in an oven overnight, and as-obtained amorphous sample heated to $850^{\circ} \mathrm{C}$ with heating rate of $10^{\circ} \mathrm{C} \mathrm{min}^{-1}$ and then kept at $850^{\circ} \mathrm{C}$ under air atmosphere for $10 \mathrm{~h}$. The final samples were obtained after being cooled to room temperature with cooling rate of $1^{\circ} \mathrm{C}$ $\min ^{-1}$."

Characterization. The PXRD pattern was collected at room temperature on a PANalytical X'-Pert Pro diffractometer in Debye-Scherrer geometry with $\mathrm{Cu} \mathrm{K \alpha} \alpha_{1}$ radiation with a minimum FWHM of $0.028^{\circ}$. The RED data collection and processing were performed using RED data collection and processing software ${ }^{[15]}$ on a JEOL-2100 electron microscope operated at $200 \mathrm{kV}$ using a single-tilt tomography sample holder. Crystals with sizes almost $400 \mathrm{~nm}$ were used for RED data collection. Using the intensities obtained from RED data, the structures were solved $a b$ inito by the software package SHELX. Total scattering neutron powder diffraction (PND) data were collected from the Polaris beamline at ISIS, Rutherford Appleton Laboratory, U.K. The structure models derived from the RED data were used as initial models for Rietveld refinements by combining PXRD with PND with the software Topas 5.1. The ${ }^{57} \mathrm{Fe}$ Mossbauer spectra were obtained using ${ }^{57} \mathrm{Co}$ diffused into rhodium as a source of gamma rays at room temperature. UV-vis spectra were recorded on a HITACHI U4100 UV-Vis spectrophotometer. The Mott-Schottky plots were measured in three-electrode cell using electrochemical analyzer, $\mathrm{CHI} 660 \mathrm{E}$, as described in the previous report. ${ }^{[19]}$ The samples were coated on conductive substrate (FTO), serving as working electrode. Platinum was used as counter electrode, and $\mathrm{Ag} / \mathrm{AgCl}$ in $3 \mathrm{M}$ $\mathrm{KCl}$ was the reference electrode. $0.1 \mathrm{M} \mathrm{Na} \mathrm{Na}_{2} \mathrm{SO}_{4}$ solution (adjusted to $\mathrm{pH} 2$ by $\mathrm{H}_{2} \mathrm{SO}_{4}$ ) was selected as electrolyte. $\mathrm{AC}$ amplitude and frequency were $10 \mathrm{mV}$ and $1 \mathrm{kHz}$, respectively.

\section{RESULTS AND DISSCUSSION}

For discovering new inorganic materials, it is not very easy to obtain pure samples in the initial syntheses of a new chemical system. PXRD is always the standard method as an initial step for characterizing polycrystalline materials. However, PXRD presents all phases in the sample, which makes it difficult to determine unknown structures in impure samples. If there is no simple match between observed pattern and crystal database, phase identification is needed by other characterization. RED overcomes most of the drawbacks of PXRD for identifying interesting new phases in as-synthesized polycrystalline samples as the RED data was collected on nano- or micrometer-sized single crystals. 


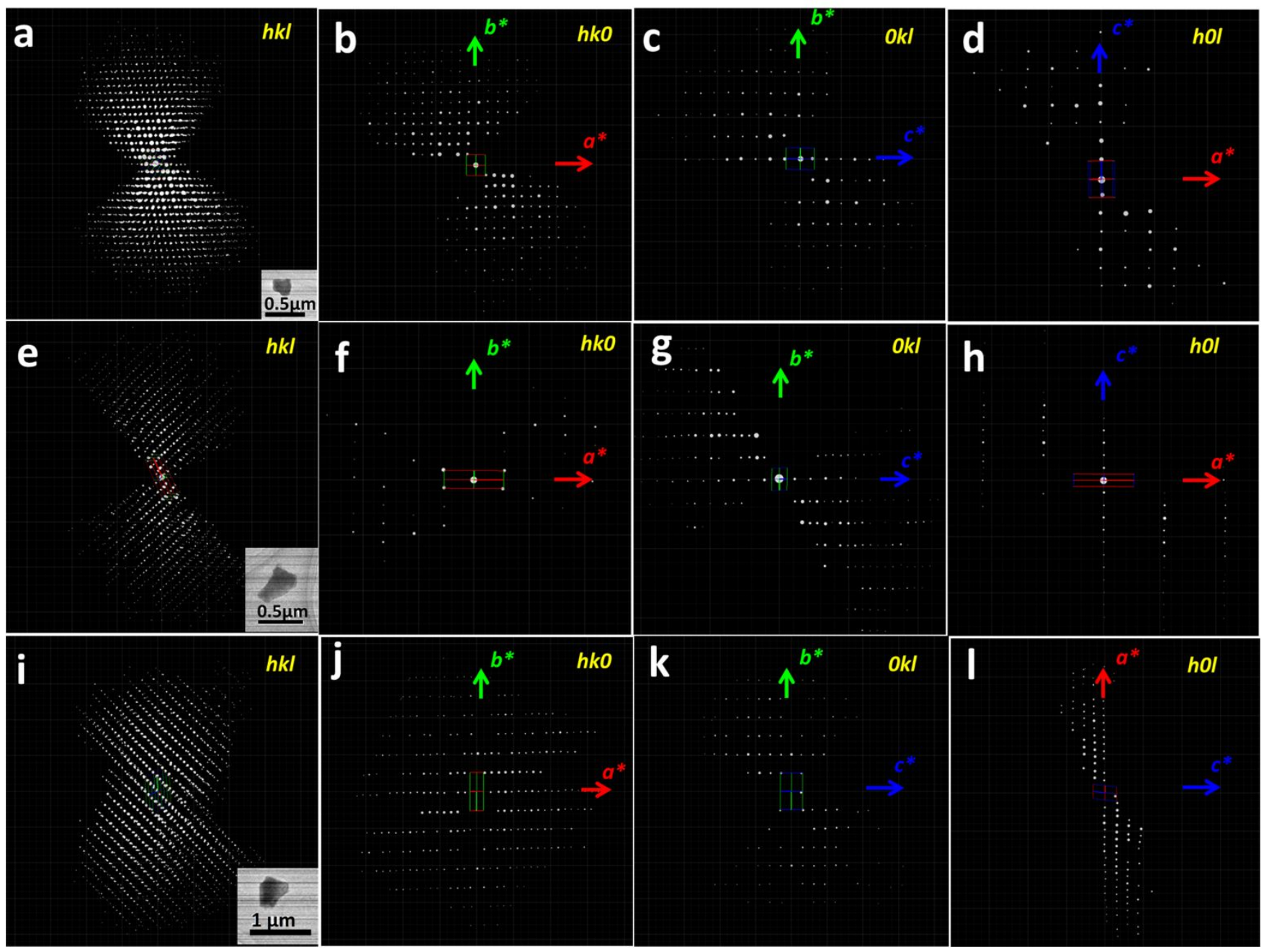

Figure 1 The 3D reciprocal lattice reconstructed from the RED data of Phase 1 (a), Phase 2 (e) and Phase 3 (i). (b) (hk0), (c) ( $0 k l)$ and (d) ( $h 0 l)$ slices cut from the reconstructed reciprocal lattice of Phase 1, reflection conditions : $0 k l: k=2 \mathrm{n}, h 0 l: h=2 \mathrm{n}, h 00: h=2 \mathrm{n}$, $0 k 0: k=2 \mathrm{n}$. (f) $(h k 0),(\mathrm{g})(0 k l)$ and $(\mathrm{h})(h 0 l)$ slices cut from the reconstructed reciprocal lattice of Phase 2, reflection conditions : $0 k l$ : $k=2 \mathrm{n}, h 0 l: h=2 \mathrm{n}, l=2 \mathrm{n}, h k 0: h+k=2 \mathrm{n}, h 00: h=2 \mathrm{n}, 00 l: l=2 \mathrm{n} .(\mathrm{j})(h k 0),(\mathrm{k})(0 k l)$ and (l) $(h 0 l)$ slices cut from the reconstructed reciprocal lattice of Phase 3, reflection conditions: 0k0: $k=2 \mathrm{n}$.

Seven compositions in the relative $\mathrm{Bi}$ poor area (named composition T1-T7) were selected in the $\mathrm{Bi}_{2} \mathrm{O}_{3}-\mathrm{Fe}_{2} \mathrm{O}_{3}-\mathrm{TiO}_{2}$ system (Figure S1, Table S1), and polycrystalline samples were obtained. Based on the PXRD data, all reflections in the sample of T1, T2, T4, and T6 can be identified as known compounds. Rietveld refinement, using all the crystallographic parameter of these known phases, confirmed that the PXRD peaks of T1, T2, T4, and T6 could be indexed by $50 \mathrm{wt} \% \mathrm{Bi}_{2} \mathrm{Fe}_{4} \mathrm{O}_{9}+37 \mathrm{wt} \% \mathrm{Fe}_{2} \mathrm{O}_{3}+13 \mathrm{wt} \% \mathrm{Bi}_{5} \mathrm{Ti}_{3} \mathrm{FeO}_{15}$, $40 \mathrm{wt} \%$ defect pyrochlore $\left(\mathrm{Bi}_{1.74} \mathrm{Ti}_{2} \mathrm{O}_{6.624}\right)+33 \mathrm{wt} \% \mathrm{Fe}_{2} \mathrm{O}_{3}+$ $27 \mathrm{wt} \% \mathrm{Fe}_{2} \mathrm{TiO}_{5}, 71 \mathrm{wt} \%$ defect pyrochlore $+25 \mathrm{wt} \%$ $\mathrm{Fe}_{2} \mathrm{TiO}_{5}+4 \mathrm{wt} \% \mathrm{Fe}_{2} \mathrm{O}_{3}$, and $97 \mathrm{wt} \%$ defect pyrochlore +3 $\mathrm{wt} \% \mathrm{Fe}_{2} \mathrm{O}_{3}$, respectively (Figure S2). However , there were some unidentified peaks in PXRD data for T3, T5 and T7 (Figure S3). Given the big difference in their compositions between $\mathrm{T} 3$ and $\mathrm{T} 5, \mathrm{~T} 7$, it was surprising to find that there were, at least, two new complex metal oxides as impurities in our ternary oxide system (Figure S3).

The very complex PXRD patterns could not be used to accomplish structure determination for unknown phases in 

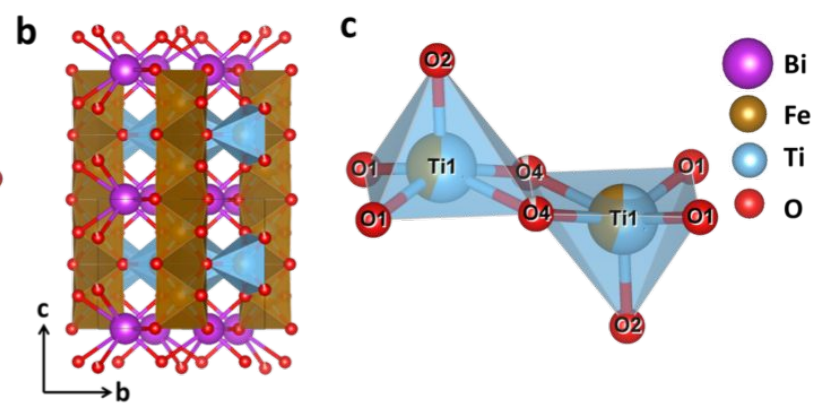

Structure model of Phase 1
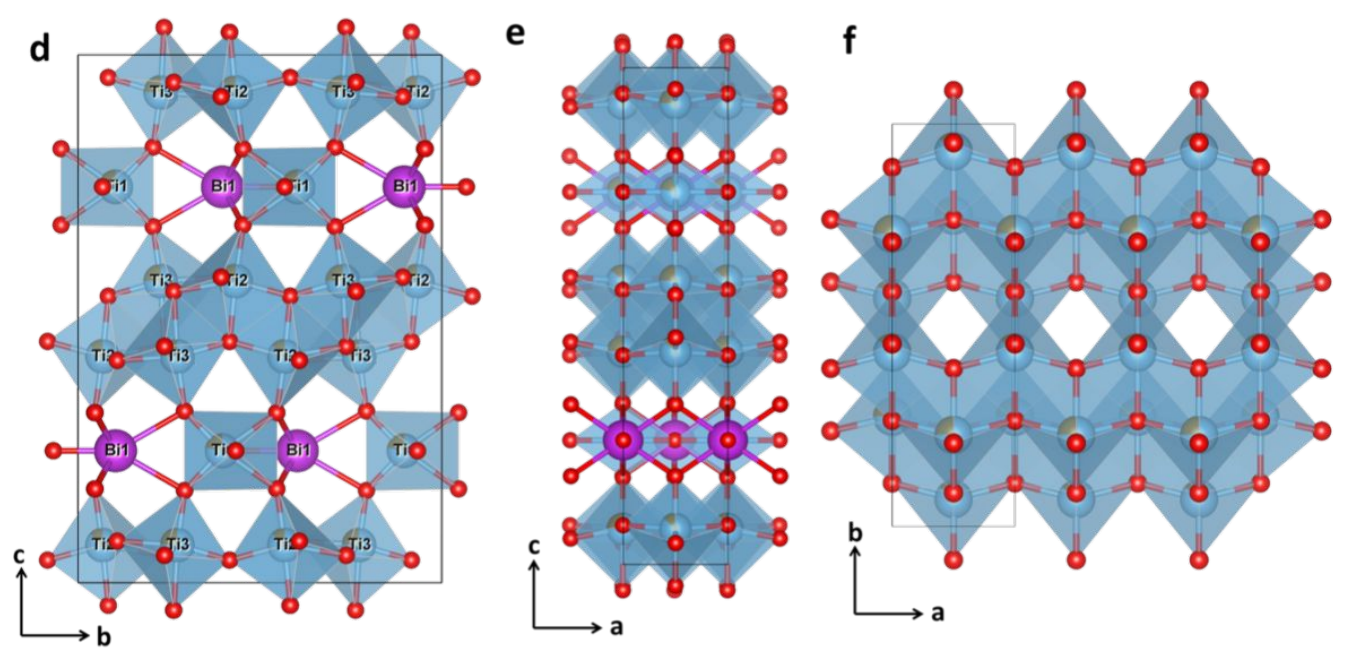

Structure model of Phase 2
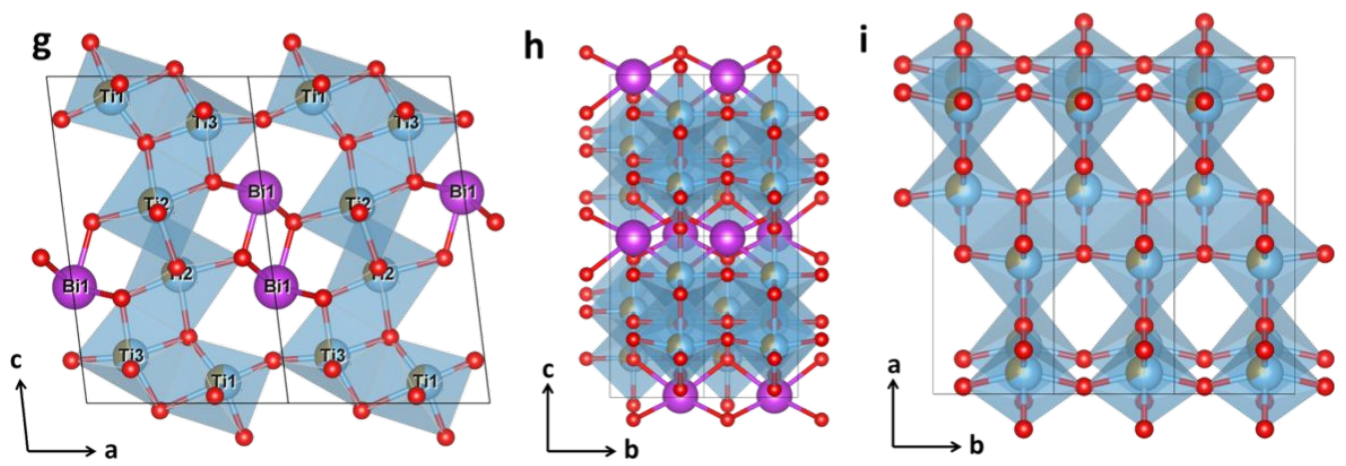

Structure model of Phase 3

Figure 2 Structure model of Phase 1 (a, b), Phase 2 (d, e) and Phase 3 (g, h) after Rietveld refinement. c, the (Fe/Ti) $)_{2} \mathrm{O}_{8}$ group formed by two edge-sharing tetragonal pyramids (Fe/Ti) $\mathrm{O}_{5}$ in Phase 1. f, the layers view along c axis in Phase 2. i, the layers view along c axis in Phase 3.

T3, T5 and T7. The RED was thus used for phase identification and structure determination. Several submicron particles in T3, T5 and T7 samples were choose to collect RED data. It was interesting to find that the reconstructed three-dimensional RED data sets from these particles showed three different unit cell parameters, which could not be found in Inorganic Crystal Structure Database (ICSD). The new phase in T3 sample was denoted as Phase 1, and another two new phases both in T5 and T7 samples were denoted Phase 2 and Phase 3. The 3D reciprocal lattice reconstructed from the RED data of Phase 1, Phase $\mathbf{2}$ and Phase $\mathbf{3}$ are shown in Figure 1. The reciprocal lattices of Phase 1 (Figure 1a-d) and
Phase 2 (Figure 1e-h) show clearly mmm Laue symmetry with the orthorhombic unit cell of $a \approx 8.61 \AA, b \approx 7.66 \AA$, $c \approx 5.93 \AA$ (Phase 1) and $a \approx 3.76 \AA, b \approx 12.29 \AA, c \approx$ $17.81 \AA$ (Phase 2), while the reciprocal lattice of Phase 3 (Figure 1i-1) shows monoclinic symmetry with the unit cell of $a \approx 10.65 \AA, b \approx 3.79 \AA, c \approx 6.53 \AA$ and $\beta \approx 97.043^{\circ}$. The reflection conditions derived from these $3 \mathrm{D}$ ED datasets in Figure 1 indicate that the possible space groups were Pbam (No. 55) and Pba2 (No. 32) for Phase 1, Cmcm (No. 63) and $C m c 2_{1}$ (No. 36) for Phase 2 and $P 2_{1}$ (No.4) and $P 2_{1} / m$ (No.11) for Phase 3, respectively. Using the unit-cell parameters and possible space groups of these three phases, 
all unidentified peaks in the PXRD patterns of T3, T5 and T7 samples could now be indexed by the Lebail fitting (Figure S4).
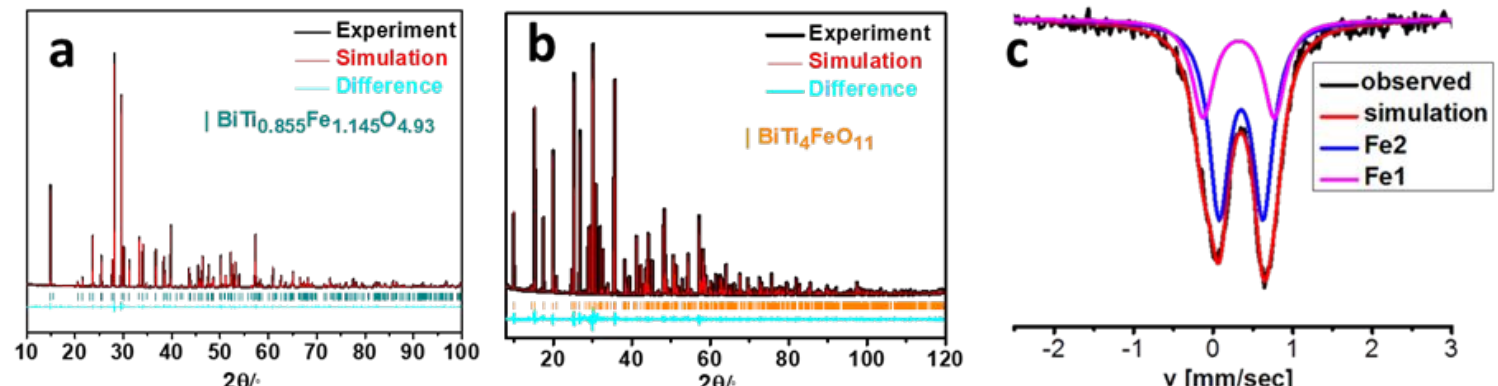

atoms (Figure 2d). The structure of Phase 2 consists of $(\mathrm{Fe} / \mathrm{Ti}) \mathrm{O}_{6}$ octaheda layer in the ab plane by edge-sharing and corner-sharing. The $(\mathrm{Fe} / \mathrm{Ti}) \mathrm{O}_{6}$ octaheda layers are linked by $\mathrm{BiO}_{7}$ polyhedra and the third $(\mathrm{Fe} / \mathrm{Ti}) \mathrm{O}_{6}$ octahedra in the $4 \mathrm{c}$

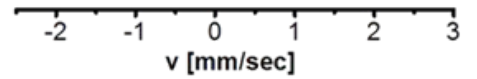

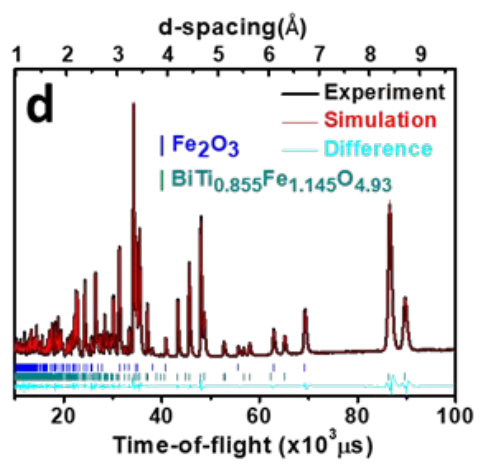
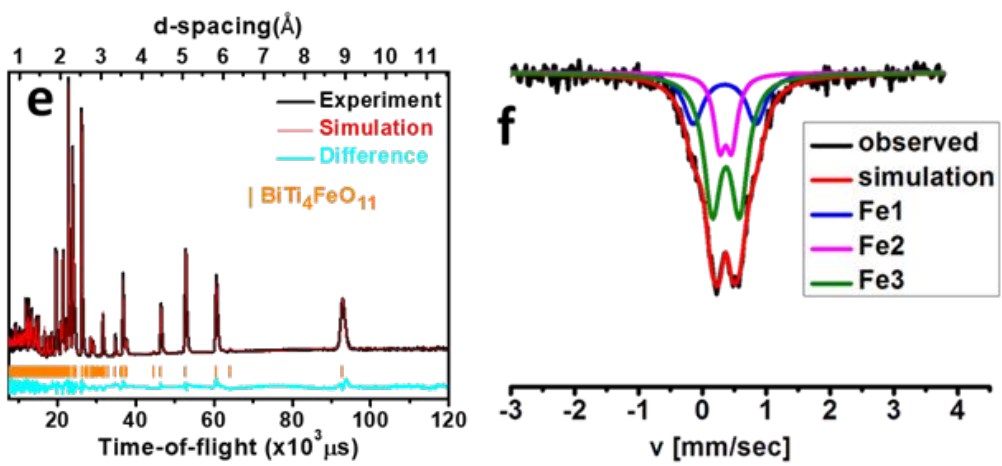

Figure 3 Rietveld refinement performed on PXRD of Phase 1(a), Phase 2 (b) and PND of Phase 1(d), Phase 2 (e). (c) Mossbauer spectroscopy of Phase 1. Fe1 was the five-coordinated Fe/Ti, while $\mathrm{Fe} 2$ belongs to six-coordinated $\mathrm{Fe} / \mathrm{Ti}$. (f) Mossbauer spectroscopy of Phase 2. $\mathrm{Fe} 1, \mathrm{Fe} 2$ belong to the two $\mathrm{Fe} / \mathrm{Ti}$ in $8 f$ site and $\mathrm{Fe} 3$ belongs to $\mathrm{Fe} / \mathrm{Ti}$ in $4 c$ site. Note that the impure peak in PND of Phase 1(d) was magnetic diffraction peak $\mathrm{Fe}_{2} \mathrm{O}_{3}$.

$\mathrm{Ab}$ initio structure solutions based on the RED datasets were performed by direct methods using the program SHELX 97 ${ }^{[20]}$. All the Bi, Ti/Fe (Ti and Fe mixed occupancy) and part of oxygen atoms in the structures of Phase 1, Phase 2 and Phase 3 were located directly with the space group of Pbam, $\mathrm{Cmcm}$ and $\mathrm{P} 2_{1} / \mathrm{m}$, respectively, and the remaining oxygen atoms were then found by electron density difference map. The structure of Phase 1 (Figure 2a) has seven symmetryindependent atoms (one $\mathrm{Bi}$, two $\mathrm{Fe} / \mathrm{Ti}$ and four $\mathrm{O}$ atoms) with rough formula of $\mathrm{BiTi}_{\mathrm{x} 1} \mathrm{Fe}_{2-\mathrm{x} 1} \mathrm{O}_{4.5+0.5 \times 1}(0<\mathrm{x} 1<2)$. The $\mathrm{Fe} / \mathrm{Ti}$ in the $4 \mathrm{f}$ site was octahedral $(\mathrm{Fe} / \mathrm{Ti}) \mathrm{O}_{6}$ coordination and extended parallel to the $\mathrm{c}$ axis as a chain by edgesharing. The octahedral chains are linked via the highly asymmetric $\mathrm{BiO}_{8}$ polyhedra and via $(\mathrm{Fe} / \mathrm{Ti})_{2} \mathrm{O}_{8}$ group formed by two edge-sharing tetragonal pyramids $(\mathrm{Fe} / \mathrm{Ti}) \mathrm{O}_{5}(\mathrm{Fe} / \mathrm{Ti}$ in $4 \mathrm{~h}$ site). The $(\mathrm{Fe} / \mathrm{Ti})_{2} \mathrm{O}_{8}$ group are arranged in the ab plane and alternate with $\mathrm{BiO}_{8}$ groups along the $\mathrm{c}$ axis (Figure $2 \mathrm{~b}$ ). The most striking feature of Phase $\mathbf{1}$ is the presence of fivecoordinated iron/titanium (Figure 2c). Up to now, only four other examples of five-coordinated iron $\left(\mathrm{FeAsO}_{4}{ }^{[21]}, \mathrm{Fe}_{3} \mathrm{PO}_{7}\right.$ [22], $\left.\mathrm{Fe}_{4}\left(\mathrm{PO}_{4}\right)_{2} \mathrm{O}{ }^{[23]} \mathrm{Cs}_{3} \mathrm{Fe}_{5} \mathrm{O}(\mathrm{OH})\left(\mathrm{AsO}_{4}\right)_{5}{ }^{[24]}\right)$ and one example of five-coordinated titanium $\left(\mathrm{Cs}_{2}(\mathrm{TiO})\left(\mathrm{P}_{2} \mathrm{O}_{7}\right){ }^{[25]}\right)$ in oxide systems are found.

The structure of Phase 2 contained ten symmetryindependent atoms with the rough formula of $\mathrm{BiTi}_{\mathrm{x} 2} \mathrm{Fe}_{5}$ ${ }_{x 2} \mathrm{O}_{9+0.5 \times 2}(0<\mathrm{x} 2<5)$, including one $\mathrm{Bi}$, three $\mathrm{Fe} / \mathrm{Ti}$, and six $\mathrm{O}$ site (Figure 2d-f). The Phase 3 contained one Bi, three Fe/Ti, and seven $\mathrm{O}$ symmetry-independent atoms, and all the atoms were in $2 \mathrm{e}$ sites with rough formula of $\mathrm{BiTi}_{x 3} \mathrm{Fe}_{3-\times 3} \mathrm{O}_{6+0.5 \times 3}$ $(0<\mathrm{x} 3<3)$ (Figure 2g). As the same with Phase 2, there was an $(\mathrm{Fe} / \mathrm{Ti}) \mathrm{O}_{6}$ octahedra layer that extended in the ab plane in Phase 3. These layers were connected by sharing an $\mathrm{O}$ atom and the $\mathrm{Bi}_{2} \mathrm{O}_{8}$ polyhedra (Figure $2 \mathrm{~g}-\mathrm{i}$ ).

In order to obtain the pure sample, it was very important to know the accurate formula of these three new oxides. As mentioned above, the rough formula of Phase 1, Phase 2 and Phase 3, which based on the structures obtained from the RED method, are $\mathrm{BiTi}_{\mathrm{x} 1} \mathrm{Fe}_{2-\times 1} \mathrm{O}_{4.5+0.5 \times 11} \quad(0<\mathrm{x} 1<2)$, $\mathrm{BiTi}_{\mathrm{x} 2} \mathrm{Fe}_{5-\mathrm{x} 2} \mathrm{O}_{9+0.5 \times 2} \quad(0<\mathrm{x} 2<5)$ and $\mathrm{BiTi}_{\mathrm{x} 3} \mathrm{Fe}_{3-\times 3} \mathrm{O}_{6+0.5 \times 3}$ $(0<x 3<3)$, respectively. Owing to the stable oxidation states of bismuth, iron and titanium under high temperature synthesis conditions as $\mathrm{Bi}^{3+}, \mathrm{Fe}^{3+}$ and $\mathrm{Ti}^{4+}$, the values of $\mathrm{x} 1$, $\mathrm{x} 2$ and $\mathrm{x} 3$ can be figured out as $\mathrm{x} 1=1, \mathrm{x} 2=4$ and $\mathrm{x} 3=2$ quickly through the charge balance. So the accurate formula of Phase 1, Phase 2 and Phase 3 should be $\mathrm{BiTiFeO}_{5}$, $\mathrm{BiTi}_{4} \mathrm{FeO}_{11}$ and $\mathrm{BiTi}_{2} \mathrm{FeO}_{7}$ if there was no defect in structures. Energy dispersive spectroscopy (EDS) results have a good agreement with the compositions that deduced from structure models within the limits of error (Figure S5). The pure samples of Phase 2 (Figure S6b) and Phase 3 (Figure S6c) were then successfully synthesized with the formula of $\mathrm{BiTi}_{4} \mathrm{FeO}_{11}$ and $\mathrm{BiTi}_{2} \mathrm{FeO}_{7}$, respectively. 

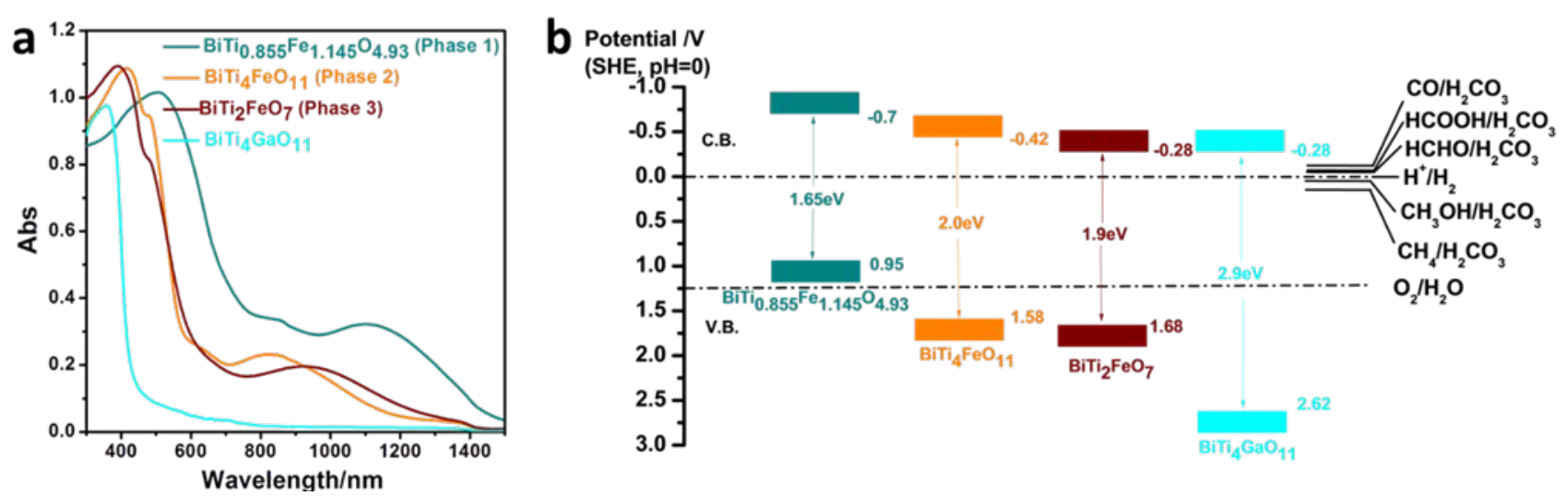

Figure $4 \mathrm{UV}$-vis diffuse reflectance spectrum of $\mathrm{BiTi}_{0.855} \mathrm{Fe}_{1.145} \mathrm{O}_{4.93}, \mathrm{BiTi}_{4} \mathrm{FeO}_{11}, \mathrm{BiTi}_{2} \mathrm{FeO}_{7}$ and $\mathrm{BiTi}_{4} \mathrm{GaO}_{11}$ (a). The conduction band minimum (CBM) and the valence band maximum (VBM) of $\mathrm{BiTi}_{0.855} \mathrm{Fe}_{1.145} \mathrm{O}_{4.93}, \mathrm{BiTi}_{4} \mathrm{FeO}_{11}, \mathrm{BiTi}_{2} \mathrm{FeO}_{7}$ and $\mathrm{BiTi}_{4} \mathrm{GaO}_{11}$ based on flat-band potential and band gap (b).

However, there were still some impure of $\mathrm{Bi}_{1.74} \mathrm{Ti}_{2} \mathrm{O}_{6.624}$ in Phase 1 for the synthesis composition of $\mathrm{BiTiFeO}_{5}$ (Figure S1, Figure S7). As we know, the PXRD intensity of a certain diffraction peak is proportional to the amount of the corresponding phase ${ }^{[26]}$. Thus, the ratio of the moles of the Phase 1 and $\mathrm{Bi}_{1.74} \mathrm{Ti}_{2} \mathrm{O}_{6.624}$ in the sample of $\mathrm{BiTiFeO}_{5}$ can be estimated by the intensity of selected diffraction peaks $\left(\mathrm{I}_{h k l}\right.$ (Phase 1) / $\mathrm{I}_{h k l}\left(\mathrm{Bi}_{1.74} \mathrm{Ti}_{2} \mathrm{O}_{6.624}\right)$ by Lebail fitting (Figure S7) and the value of $\mathrm{x} 1$ in $\mathrm{BiTi}_{\mathrm{x} 1} \mathrm{Fe}_{2-\times 1} \mathrm{O}_{4.5+0.5 \times 11}$ can be narrowed to $0.80<\mathrm{x} 1<0.90$ with less Ti in Phase 1 . We revised the synthesis composition for Phase $\mathbf{1}$ and the final pure sample of Phase 1 (Figure S6a) was obtained when $\mathrm{BiO}_{1.5}: \mathrm{TiO}_{2}: \mathrm{FeO}_{1.5}=1: 0.855: 1.145$. Therefore, the accurate formula of Phase $\mathbf{1}$ should be $\mathrm{BiTi}_{0.855} \mathrm{Fe}_{1.145} \mathrm{O}_{4.93}$.

Later, the structure solutions were also performed on PXRD. The same structural models of Phase 1, Phase 2 and Phase 3 were successfully reproduced from high-resolution PXRD by SUPERFIP [27], confirming the structure models from RED data . However, the most challenge for Rietveld refinement of high-resolution PXRD was that X-ray could not distinguish the $\mathrm{Ti}$ and $\mathrm{Fe}$ effectively, as their X-ray scattering lengths are very close. Fortunately, drastically different neutron scattering lengths of $\mathrm{Fe}$ and $\mathrm{Ti}(9.45 \mathrm{fm}$ for $\mathrm{Fe},-3.44 \mathrm{fm}$ for $\mathrm{Ti}$ ) allows the refinement of the occupancies for the $\mathrm{Fe} / \mathrm{Ti}$ mixed positions. Thus, structures of $\mathrm{BiTi}_{0.855} \mathrm{Fe}_{1.145} \mathrm{O}_{4.93}$ and $\mathrm{BiTi}_{4} \mathrm{FeO}_{11}$ were successfully refined by combining PXRD (Figure 3a, 3b) and PND (Figure 3d, $3 \mathrm{e})$. From the refined structures, the occupancies of $\mathrm{Fe}$ and $\mathrm{Ti}$ in the five-coordinated $\mathrm{Fe} / \mathrm{Ti}$ site of Phase 1 were 0.445 and 0.555 , which is very unusual in iron and titanium metal oxides. In order to confirm the refined distribution of $\mathrm{Fe}$ and Ti in the Phase 1, Phase 2, the Mossbauer spectroscopy was used to analyze the local coordination environment of $\mathrm{Fe}$ atoms under room temperature. The spectra of Phase $\mathbf{1}$ can be fitted with two overlapping paramagnetic doublets (Figure $3 \mathrm{c}$ ), while the Phase $\mathbf{2}$ needed three overlapping paramagnetic doublets to fit well (Figure 3f). From the result of Mossbauer spectroscopy, the ratios of $\mathrm{Fe}$ in the two $\mathrm{Fe} / \mathrm{Ti}$ site of Phase 1 were 35\% (five-coordinated $\mathrm{Fe} / \mathrm{Ti}$ ) and $65 \%$ (six-coordinated $\mathrm{Fe} / \mathrm{Ti}$ ). In the three $\mathrm{Fe} / \mathrm{Ti}$ site of Phase 2, the ratios of $\mathrm{Fe}$ were $23 \%, 27 \%$ and $50 \%$, respectively. All the results of Mossbauer spectroscopy were in a good agreement with the PND refinement. It should be noted that the occupancy of $\mathrm{O} 4$ in $4 \mathrm{e}$ site was 0.93 as the composition of Phase 1 was deviated from BiTiFeO5, after doing Rietveld refinements by combing PXRD and PND, while there was no oxygen defect observed in Phase 2. In addition, bond distances and angles fall within the expected ranges for ionic interactions, which further confirmed that the structure models of Phase 1 and Phase 2 were high quality. Bond valence sums (BVS) was measured the bond strength in ionic compounds using all interactions up to a distance of $3 \AA$ are shown in Table S4 (Phase 1) and Table S7 (Phase 2). As expected, the BVS analysis showed that the average valence states of the $\mathrm{Bi}, \mathrm{Fe}$, and $\mathrm{Ti}$ ions in Phase 1 and Phase 2 were $\mathrm{Bi}^{3+}, \mathrm{Fe}^{3+}$ and $\mathrm{Ti}^{4+}$. The detailed crystallographic data of $\mathrm{BiTi}_{0.855} \mathrm{Fe}_{1.145} \mathrm{O}_{4.93}$ and $\mathrm{BiTi}_{4} \mathrm{FeO}_{11}$ is shown in Table S2, Table S3, Table S5, and Table S6, respectively. It was interesting that another new phase $\mathrm{BiTi}_{4} \mathrm{GaO}_{11}$, which is isostructural with $\mathrm{BiTi}_{4} \mathrm{FeO}_{11}$, can be obtained when replacing $\mathrm{Fe}$ in $\mathrm{BiTi}_{4} \mathrm{FeO}_{11}$ with $\mathrm{Ga}$ (Figure S8). As the Phase 3 is a metastable phase, it was easy to transfer to Phase 2 under the synthesis conditions, thus we just obtained $0.8 \mathrm{~g}$ pure sample so far. The structure model was refined only by high-resolution PXRD, with fixing the occupancies of $\mathrm{Fe}$ and $\mathrm{Ti}$ as 0.3333 and 0.6667 in $\mathrm{Fe} / \mathrm{Ti}$ site. (Figure S9, Table S8, Table S9).

In order to explore the potential application of these four new complex metal oxide materials, the band structures were investigated by UV-vis diffuse reflectance spectrum and flatband potential measurement. UV-vis diffuse reflectance spectrum of $\mathrm{BiTi}_{0.855} \mathrm{Fe}_{1.145} \mathrm{O}_{4.93}, \mathrm{BiTi}_{4} \mathrm{FeO}_{11}, \mathrm{BiTi}_{2} \mathrm{FeO}_{7}$ and $\mathrm{BiTi}_{4} \mathrm{GaO}_{11}$ exhibited the absorption edge at $752 \mathrm{~nm}, 620 \mathrm{~nm}$, $652 \mathrm{~nm}$ and $443 \mathrm{~nm}$, respectively, whose corresponding bandgaps were $1.65,2.0,1.9$ and $2.8 \mathrm{eV}$, respectively (Figure 4a). Mott-Schottky plots were used to determine the flat-band potential of the four new complex metal oxide materials. In an aqueous $\mathrm{Na}_{2} \mathrm{SO}_{4}$ solution $(\mathrm{pH}=2)$, the flat- 
band potentials of $\mathrm{BiTi}_{0.855} \mathrm{Fe}_{1.145} \mathrm{O}_{4.93}, \quad \mathrm{BiTi}_{4} \mathrm{FeO}_{11}$, $\mathrm{BiTi}_{2} \mathrm{FeO}_{7}$ and $\mathrm{BiTi}_{4} \mathrm{GaO}_{11}$ were $-0.90,-0.62,-0.48$ and $0.48 \mathrm{eV}$ vs $\mathrm{Ag} / \mathrm{AgCl}(-0.70,-0.42,-0.28,-0.28 \mathrm{eV}$ vs SHE), respectively (Figure S10). Given that the flat-band potential is located just below conduction band minimum (CBM), the valence band maximum (VBM) of $\mathrm{BiTi}_{0.855} \mathrm{Fe}_{1.145} \mathrm{O}_{4.93}$, $\mathrm{BiTi}_{4} \mathrm{FeO}_{11}, \mathrm{BiTi}_{2} \mathrm{FeO}_{7}$ and $\mathrm{BiTi}_{4} \mathrm{GaO}_{11}$ was estimated to be $0.95,1.58,1.68$ and $2.62 \mathrm{eV}$ vs SHE, using its band gap (Figure 4b).

\section{CONCLUSIONS}

In summary, three new complex metal oxide materials $\left(\mathrm{BiTi}_{0.855} \mathrm{Fe}_{1.145} \mathrm{O}_{4.93}, \quad \mathrm{BiTi}_{4} \mathrm{FeO}_{11}, \quad \mathrm{BiTi}_{2} \mathrm{FeO}_{7}\right)$ were discovered in $\mathrm{Bi}_{2} \mathrm{O}_{3}-\mathrm{Fe}_{2} \mathrm{O}_{3}-\mathrm{TiO}_{2}$ system by $3 \mathrm{D}$ ED techniques and a new phase $\mathrm{BiTi}_{4} \mathrm{GaO}_{11}$, which is isostructural with $\mathrm{BiTi}_{4} \mathrm{FeO}_{11}$, was obtained when replacing $\mathrm{Fe}$ in $\mathrm{BiTi}_{4} \mathrm{FeO}_{11}$ with $\mathrm{Ga}$. To our best knowledge, it is the first time to discover three new complex metal oxide materials with new structure types in a single study of ternary metal oxide system. Thus, 3D ED technique, such as RED, is a powerful method to fasten the discovery of new complex metal oxide materials, which is no need for pure sample or single crystal growth. The band structures of the newly discovered new complex metal oxide materials were also investigated by UV-vis diffuse reflectance spectrum and flat-band potential measurement. They were semiconductors with bandgap of 1.65, 2.0, 1.9 and $2.8 \mathrm{eV}$, respectively. This study demonstrates a successful strategy of rapidly developing new inorganic functional materials and this method for developing new materials is available to all fields in chemistry and material chemistry where the limiting factors are impurity, submicrometer-sized crystals, etc.

\section{ASSOCIATED CONTENT}

Supporting Information

The Supporting Information is available free of charge on the ACS Publications website.

Figures S1-S10, and Tables S1-S9 (PDF)

Structure Phase_1_BiTi ${ }_{0.855} \mathrm{Fe}_{1.145} \mathrm{O}_{4.93}$ (CIF)

Structure Phase_2_BiTi $\mathrm{FeO}_{11}(\mathrm{CIF})$

Structure Phase_3_BiTi ${ }_{2} \mathrm{FeO}_{7}$ (CIF)

3D_ED_data_Phase_1 (AVI)

3D_ED_data_Phase_2 (AVI)

3D_ED_data_Phase_3 (AVI)

\section{AUTHOR INFORMATION}

Corresponding Author

*junliang.sun@pku.edu.cn

\section{Notes}

The authors declare no competing financial interest.

\section{ACKNOWLEDGMENT}

This project is supported by National Natural Science Foundation of China and Ministry of Science and Technology of the People's Republic of China (No. 21871009, 21621061, 21527803, 21471009, 2016YFA0301004). We also acknowledge the Polaris beamline at ISIS, Rutherford Appleton Laboratory, U.K.

\section{REFERENCES}

[1] B. C. H. Steele; A. Heinzel, Materials for fuel-cell technologies. Nature, 2001, 414, 345-352.

[2] D. J. L. Brett; A. Atkinson; N. P. Brandon; S. J. Skinner, Intermediate temperature solid oxide fuel cells. Chem. Soc. Rev., 2008, 37, 1568.

[3] Y. Cho; S. Lee; T. Hong; J. Cho; Spinel-layered coreshell cathode materials for Li-ion batteries, $A d v$. Energy Mater., 2011, 1, 821-828.

[4] K. T. Lee; S. Jeong; J. Cho; Roles of surface chemistry on safety and electrochemistry in lithium ion batrreries, Acc. Chem. Res., 2013, 46, 1161-1170.

[5] J. G. Bedncorz; K. A. Muller; Possible high Tc superconductivity in the Ba-La-Cu-O system, Z. Phys. $B$, 1986, 64, 189-193.

[6] M. K. Chu; J. R. Ashburn; C. J. Torng; P. H. Hor; R. L. Meng; L. Gao; Z. J. Huang; Y. Q. Wang; C. W. Chu; Superconductivity at $93 \mathrm{~K}$ in a new mixed-phase $\mathrm{Y}$-Ba$\mathrm{Cu}-\mathrm{O}$ compound system at ambient pressure, Phys. Rev. Let., 1987, 58, 908-910.

[7] H. Koinuma; I. Takeuchi; Combinatorial solid-state chemistry of inorganic materials, Nat. Mater., 2004, 7 , 429-438.

[8] S. Meguro; T. Ohnishi; M. Lippmaa; H. Koinuma; Elements of informatics for combinatorial solid-state materials science, Meas. Sci. Technol., 2005, 16, 309316.

[9] H. Koinuma; H. N. Aiyer; Y. Matsumoto; Combinatorial solid state materials science and technology, Sci. Technol, Adv. Mater. 2000, 1, 1-10.

[10] I. Takeuchi; R. B. van Dover; H. Koinuma; Combinatorial synthesis and evaluation of functional inorganic materials using thin-film techniques, Mater. Res. Soc. Bull.; 2002, 27, 301-308.

[11] X. D. Xiang, Combinatorial materials synthesis and screening: an integrated materials chip approach to discovery and optimization of functional materials, Annu. Rev. Mater. Sci., 1999, 29, 149-171.

[12] Y. Matsumoto; H. Koinuma; T. Hasegawa; I. Takeuchi; F, Tsui; Y. K. Yoo, Combinatorial investigation of spintronic materials, Mater. Res. Soc. Bull., 2003, 28, 734-739.

[13] Y. F. Yun; W. Wan; F. Rabbani; J. Su; H. Y. Xu; S. Hovmoller; M. Johnsson; X. D. Zou; Phase identification and structure determination from 
multiphase crystalline powder samples by rotation electron diffraction, J. Appl. Cryst., 2014, 47, 20482054.

[14] U. Kolb; T. Gorelik; C. Kubel; M. T. Otten; D. Hubert, Towards automated diffraction tomography: Part 1-data qcquisition, Ultramicroscopy, 2007, 107, 507-513.

[15] W. Wan; J. L. Sun; J. Su; S. Hovmoller; X. D. Zou; Three dimensional rotation electron diffraction software RED for automated data collection and data processing, J. Appl. Cryst. 2013, 46, 1863-1873.

[16] J. Li; J. L. Sun; Application of X-ray diffraction and electron crystallography for solving complex structure problems. Acc. Chem. Res., 2017, 50, 2737-2745.

[17] D. Batuk; A. A. Tsirlin; D. S. Filimonov; K. V. Zakharov; O. S. Volkova; A. Vasiliev; J. Hadermann; A. M. Abakumov; $\mathrm{Bi}_{3 \mathrm{n}+1} \mathrm{Ti}_{7 \mathrm{Fe}} \mathrm{nn}_{3} \mathrm{O}_{9 \mathrm{n}+11}$ Homologous series: slicing perovskite structure with planar interfaces containing anatase-like chains. Inorg. Chem. 2016, 55, 3, 1245-1257.

[18] N. A. Lomanova; V. V. Gusarov; Electrical properties of perovskite-like compounds in the $\mathrm{Bi}_{2} \mathrm{O}_{3}-\mathrm{Fe}_{2} \mathrm{O}_{3}-\mathrm{TiO}_{2}$ system, Inorg. Mater., 2011, 47, 420-425.

[19] H. Fujito; H. Kunioku; D. Kato; H. Suzuki; M. Higashi; H. Kageyama; R. Abe, Layered Perovskite Oxychloride $\mathrm{Bi}_{4} \mathrm{NbO}_{8} \mathrm{Cl}$ : A Stable Visible Ligh Responsive Photocatalyst for Water Splitting, J. Am. Chem. Soc. 2016, 138, 2082-2085.

[20] G. M. Sheldrick; A short history of SHELX. Acta Crystallographica Section A Foundations of Crystallography. 2008, 64, 112-122.

[21] A. K. Cheetham; W. I. F. David; M. M. Eddy; R. J. B. Jakeman; M. W. Johnson; C. C. Torardi; Crystal structure determination by powder neutron diffraction at the spallation neutron source, ISIS, Nature, 1986, $320,46-48$.

[22] A. Modaressi; A. Courtois; R. Geratdin; J. Steinmetz; C. Gleitzer; $\mathrm{Pe}_{3} \mathrm{PO}_{7}$, Un cas de coordinence $5 \mathrm{du}$ fer trivalent, etude structural et magnetique, J. Solid State Chem., 1983, 47, 245-255.

[23] M. Bouchdoug; A. Courtois; R. Gerardin; J. Steinmetz; C. Gleitzer; Preparation et etude d'un oxyphosphate $\mathrm{Fe}\left(\mathrm{PO}_{4}\right)_{2} \mathrm{O}$, J. Solid State Chem., 1982, 42, 149-157.

[24] B. L. Wang; S. L. Wang; K. H. Lii; $\mathrm{Cs}_{3} \mathrm{Fe}_{5} \mathrm{O}(\mathrm{OH})\left(\mathrm{AsO}_{4}\right)_{5}$, a novel iron(III) arsenate containing four-, five- and six-coordinated iron atoms, Chem. Commun. 1996, 1061-1062.

[25] J. Protas; B. M. G. Marnier; B. Boulanger; Acta Crystallographica Section C Crystal Structure Communications, 1991, 47, 698-701.

[26] R. Wang; C. X. Yang; M. Fan; M. M. Wu; C. H. Wang; X. H. Yu; J. L. Zhu; J. R. Zhang; G. B. Li; Q. Z. Huang; D. F. Chen; T. N. Jin; T. Kamiyama; F. H. Liao; J. H. Lin, Phase relationship of the $\mathrm{TbO}_{1.81}-\mathrm{Mn}_{3} \mathrm{O}_{4}-\mathrm{Fe}_{2} \mathrm{O}_{3}$ system synthesized at $1200{ }^{\circ} \mathrm{C}$, Journal of Alloys and Compounds, 2013, 554, 385-394.

[27] L. Palatinus; G. Chapuis; SUPERFLIP- a computer program for the solution of crystal structures by charge flipping in arbitrary dimensions. J. Appl. Crystallogr. 2007, 40, 786-790.

\section{For Table of Contents Only}

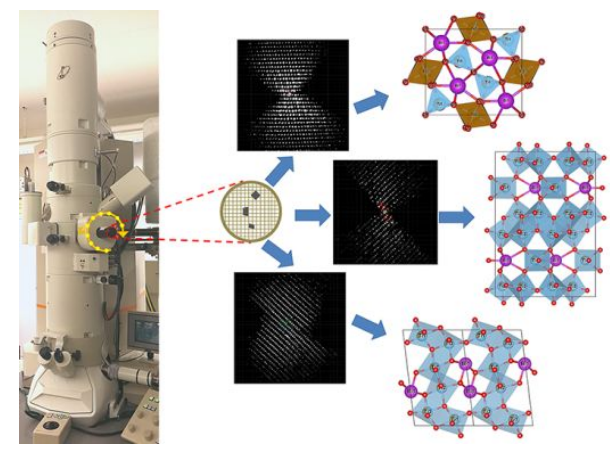




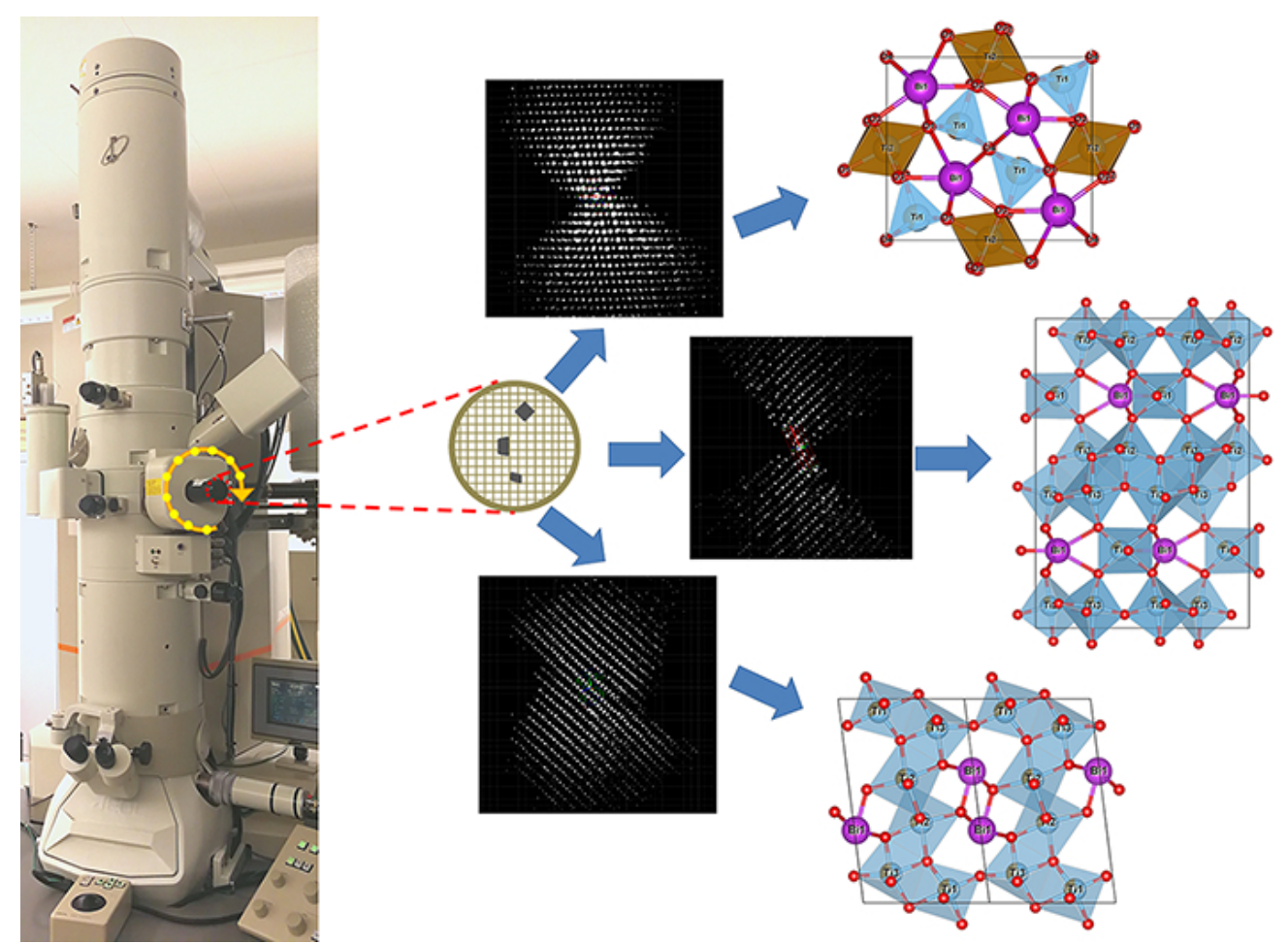

For Table of Contents Only 